\title{
PERGESERAN MAKNA MITOS NILAI SPIRITUAL KEBUDAYAAN ONDEL-ONDEL PADA KEPERCAYAAN MASYARAKAT BETAWI ZAMAN DAHULU DAN ZAMAN SEKARANG
}

\author{
Oleh: \\ Lazizah Akmaliyah, Zahratul Jannah Zulfa \& Nikmah Rochmawati \\ Universitas Islam Negeri Walisongo Semarang, Indonesia \\ LazizatulAkmaliyah@gmail.com, \\ Zahrajnnhzlff@gmail.com, \\ rahma_mewangi@walisongo.ac.id
}

\begin{abstract}
:
Ondel-ondel is a cultural performance of the Betawi people passed down from generation to generation. However, the problem that occurs is that along with the development of the era, ondel-ondel is no longer a sacred object and is no longer used for ritual offerings and the loss of cultural values of the ancestors. The purpose of making this journal is to find out the shift in the meaning of the ondel-ondel cultural myth to the beliefs of the people of Jakarta. The method used in this study uses a qualitative approach and data collection techniques use interview techniques, observation and analysis of various journals or literature studies. The subject of this research was conducted on 4 people, namely a number of the Jakarta community about their views on the shift in the meaning of the myth of ondel-ondel art. In this day and age, ondel-ondel shows are very easy to find, especially on roadside areas in Jakarta. Unlike the old days, ondel-ondel was only displayed when there were certain events such as a traditional Betawi wedding. The result of this research is that there are differences and shifts in the meaning of ondelondel cultural myths. In ancient times ondel-ondel was only displayed during certain events. And people in ancient times tend to still believe in the existing ondel-ondel cultural myths. Unlike the current era, ondelondel is used as a means of getting money. The benefit of this research is to find out what values have been lost from previous cultures and be able to take good positive values taught in previous cultures without taking the negative values found in the past culture. It is enough to make historical knowledge to remember existing history. This study concludes that there has been a shift in meaning in the myth of ondel-
\end{abstract}


ondel culture and sadly it occurs due to the pressure of economic factors.

Keyword: Kepercayaan Masyarakat, Kebudayaan, Perbedaan.

\section{A. Pendahuluan}

Menurut Hofstede yang dikutip oleh Richard D Lewis dalam bukunya yang berjudul "Komunikasi Bisnis Lintas Budaya", mendifinisikan budaya sebagai "pemrograman kolektif atas pikiran yang membedakan anggota-anggota suatu kategori orang dari kategori lainnya'. Indonesia adalah salah satu negara yang memiliki beragam suku dan budaya, salah satunya adalah suku Betawi yang merupakan kebudayaan dari daerah Jakarta. Jakarta adalah salah satu kota megapolitan di Asia yang mengalami perubahan secara fisik, sosial dan ekonomi dengan cepat. Jakarta memiliki salah satu kebudayaan, yakni Ondel-Ondel. Ondel-ondel merupakan salah satu kesenian khas Betawi ${ }^{1}$. Dari masa ke masa masyarakat Betawi terus berkembang dengan ciri-ciri budaya yang makin lama semakin mantap sehingga mudah dibedakan dengan kelompok etnis lain, namun bila dikaji secara mendalam akan tampak unsur-unsur kebudayaan yang menjadi sumber asalnya. Misalnya sebagai budaya akulturasi, persamaan dengan budaya lain dapat dilihat dengan kesamaan ciri budaya-budaya lain ${ }^{2}$. Ondel-ondel merupakan sebuah boneka raksasa yang dimaknai masyarakat Betawi sebagai budaya yang sakral dan digunakan untuk ritual persembahan kepada roh-roh leluhur. Bahkan terdaftar sebagai salah satu dari delapan ikon budaya Betawi yang diatur dalam Pergub No 11 tahun 2017 tentang ikon Budaya Betawi. Berdasarkan regulasi itu disebutkan bahwa secara filosofi ondel-ondel bermakna sebagai perlambang kekuatan yang memiliki kemampuan memelihara keamanan dan ketertiban, tegar, berani, tegas, jujur dan anti manipulasi.

Menurut Sumarjo ${ }^{3}$, ondel-ondel merupakan suatu wadah yang dijadikan personifikasi leluhur nenek moyang. Dengan demikian dapat

1 Paramita, S. Pergeseran Makna Budaya Ondel-Ondel Pada. 1(1), 2018.

2 Rosita, D. Q. Perancanaan Tipografi Asimilasi Aksara Latin Karakteristik OndelOndel sebagai Soludi Kreatif Melestarikan Budaya Betawi. Jurnal Desain, 2(2), 2014.

3 Sumardjo, Jakob dan Saini. Apresiasi Kesusastraan. (Jakarta: Gramedia Pustaka Utama. 1997), 76.

98 JURNAL LISAN AL-HAL 
dianggap sebagai pembawa lakon atau cerita, walaupun hanya sebagai alat peraga yang tidak berbicara atau bertutur. Ondel-ondel merupakan hasil dari kebudayaan Betawi yang berupa boneka besar yang tingginya mencapai sekitar $\pm 2,5 \mathrm{~m}$ dengan garis tengah $\pm 80 \mathrm{~cm}$, boneka ini dibuat dari anyaman bambu yang dibuat agar dapat dipikul dari dalam oleh orang yang membawanya. Pada wajahnya berupa topeng atau kedok yang dipakaikan ke anyaman bambu dengan kepala yang diberi rambut yang terbuat dari ijuk. Wajah ondel-ondel laki-laki biasanya di cat dengan warna merah, sedangkan yang perempuan dicat dengan warna putih. Jenis pertunjukan kesenian ondel-ondel sudah ada sejak sebelum tersebarnya agama Islam di Pulau Jawa. Awal mula masyarakat Betawi menyebutnya dengan barungan yang berasal dari kata bareng-bareng atau bersamasama. Sebutan itu datang dari kalimat ajakan dalam logat Betawi "Nyok, kite ngarak bareng-bareng".

Ondel-ondel merupakan bentuk boneka sepasang laki-laki dan perempuan ini tidak hanya sebagai simbolis semata, melainkan juga mengandung makna tersendiri bagi masyarakat Betawi. Pemahaman tentang arwah nenek moyang yang senantiasa menjaga keberlangsungan kehidupan bagi keturunannya. Sebagai perlambang penolak bala untuk segala macam bentuk musibah atau bencana yang mengancam bagi masyarakat Betawi. Ondel-ondel di masa kini memang dikenal sebagai boneka yang terbuat dari rangkaian atau susunan kerangka bambu, lengkap dengan pakaian yang dikenal khas sebagai pakaian tradisional Betawi dengan hiasan kembang kelapa di bagian kepalanya. Pemakaian bunga kelapa ini melambangkan banyak pohon kelapa di kota Jakarta, karena letaknya di daerah pesisir. Dimana banyak tumbuh pohon kelapa. Biasanya ondel-ondel ini selalu sepasang (laki-laki dan perempuan) baik untuk seni pertunjukan maupun sebagai simbol penjaga rumah (biasa diletakkan di bagian depan bangunan Pemerintah Daerah Khusus Ibukota Jakarta.

Awal mulanya pertunjukan kesenian ondel-ondel ini berfungsi sebagai penolak bala dari gangguan roh halus yang mengganggu. Semakin lama tradisi tersebut berubah menjadi hal yang sangat bagus untuk dipertontonkan, dan kebanyakan acara tersebut kini di adakan pada acara penyambutan tamu terhormat, dan untuk menyemarakkan pesta-pesta rakyat serta peresmian gedung yang baru selesai dibangun. Akan tetapi, belakangan ini keberadaan kesenian ondel-ondel kini tidak lagi 
dimanfaatkan untuk kegiatan budaya, melainkan disalahgunakan untuk kegiatan mengamen. Mereka tak lagi berjalan diiringi merdunya alunan musik tradisional Betawi. Biasanya mereka berjalan dengan membawa sebuah radio kecil yang musiknya kadang tak lagi merepresentasikan kesenian budaya Betawi. Bahkan ada yang tidak ditemani musik apapun. Mereka hanya berjalan dengan sebuah ember ditangan yang digunakan untuk meminta-minta uang kepada setiap masyarakat yang mereka temui. Ondel ondel seakan telah berubah fungsi dari alat untuk kesenian pesta rakyat, menjadi alat untuk mencari nafkah. Ondel ondel telah banyak dimanfaatkan oleh sebagian kalangan untuk menangguk untung, dengan alasan mencari uang.Dengan maraknya peristiwa tersebut menyebabkan masyarakat Betawi menaruh perhatian terkait penggunaan Ondel-ondel ngamen terlebih lagi Ondel-ondel tersebut tidak menggunakan menggunakan pakaian yang layak, jarang tampil berpasangan, dan tidak menggunakan peralatan yang lengkap seperti alat musik maupun pakaian adat untuk pemainnya. Pakaian yang kurang layak menimbulkan rasa prihatin bercampur kesal di kalangan masyarakat Betawi. Dengan pakaian dan juga peralatan yang kurang lengkap membuat para pemain Ondelondel terlihat hanya untuk memenuhi kepentingannya semata.

Seiring perjalanan waktu, ondel-ondel kini tidak hanya ditemui pada pesta rakyat ataupun penyambutan tamu. Jikaberjalan menyusuri jalanan ibukota, maka kita akan dengan mudah menjumpai Ondel-ondel yang tak lagi berjalan berpasangan. Mereka tak lagi berjalan diiringi merdunya alunan musik tradisional Betawi. Biasanya mereka berjalan dengan membawa sebuah radio kecil yang musiknya

kadang tak lagimerepresentasikan kesenian budaya Betawi. Bahkan ada yang tidak ditemani musik apapun. Mereka hanya berjalan dengan sebuah ember ditangan yang digunakan untuk meminta-minta uang kepada setiap masyarakat yang mereka temui. Ondel ondel seakan telah berubah fungsi dari alat untuk kesenian pesta rakyat, menjadi alat untuk mencari nafkah. Ondel ondel telah banyak dimanfaatkan oleh sebagian kalangan untuk menangguk untung, dengan alasan mencari uang. Ketidakmapanan ekonomi menjadi alasan klasik yang biasa disebutkan mengapa mereka turun kejalan dengan memanfaatkan ondel ondel. Selain itu, banyaknya penduduk luar kota Jakarta yang datang ke ibu kota menimbulkan banyak permasalahan sosial dan kesenjangan ekonomi. Kondisi tersebut menyebabka meningkatnya pengangguran hingga 
bermuara pada bertambahnya jumlah Penyandang Masalah Kesejahteraan Sosial (PMKS) di Jakarta. Salah satunya ialah munculnya pengamen Ondelondel. Pengamen ondel ondel yang datang dari luar luar kota itu bukanlah orang Betawi yang tentu saja tidak memahami apa dan bagaimana fungsi Ondel-Ondel yang sebenarnya. Pemerintah4 ${ }^{4}$ Penyalahgunaan kegiatan kebudayaan seperti ini dilakukan oleh para pengamen yang berasal dari masyarakat Jakarta itu sendiri.Pada penelitian ini, peneliti memfokuskan penelitian pada beberapa aspek guna mempermudah peneliti dalam melakukan penelitian. Fokus penelitian tersebut yakni perubahan makna kepercayaan masyarakat Jakarta tentang mitos kebudayaan ondel-ondel. Terutama perbandingan kepercayaan pada masyrakat zaman saat ini dan zaman dahulu.

Pelestarian mitos ini sangat penting untuk menjaga persatuan dan stabilitas keamanan masyarakat Betawi. Tetapi harus diingat bahwa tidak ada mitos yang abadi karena sejarah manusialah yang mengubah kenyataan menjadi bentuk pembicaraan dan sejarah manusia sendirilah yang mengatur kehidupan dan kematian bahasa mitis. Kuno atau tidak, mitologi hanya dapat memiliki fondasi sejarah karena mitos adalah sebuah jenis pembicaraan yang dipilih oleh sejarah ${ }^{5}$. Oleh karena itu mitos barongan pada masa dari zaman penjajahan Belanda hingga tahun 1970an diciptakan untuk kepentingan masa itu. Pada masa sebelumnya bentuk barongan atau barong juga telah ada, tetapi mitos yang diciptakan pada masa itu tentu berbeda.

Manfaat dan pentingnya dari penelitian ini antara lain guna untuk mengetahui aspek aspek apa saja yang sudah hilang dari kebudayaan ondel-ondel dari jaman dahulu hingga pada zaman sekarang. Dari penelitian ini pembaca dapat mengerti nilai nilai negatif dan positif yang diajarkan dari kebudayaan pada zaman dahulu tanpa mengambil nilai negatif. Cukup untuk dijadikan sebagai ilmu pengetahuan sejarah kebudayaan Betawi yang memiliki keunikan tersendiri dalam kesenianya dan tidak melupakan cerita sejarah yang sudah ada. Keunikan dari tulisan ini, pembaca bisa melihat dari sudut pandang tokoh masyarakat dari sesepuh masyarakat betawi dan sudut pandang anak muda masyarakat

4 Majid, A. N., \& Ikhwan, M. Visualisasi Film Dokumenter Potret Pergeseran Fungsi Dan Penggunaan Ondel-Ondel Betawi. Journal of Chemical Information and Modeling, 110(9), 1689-1699. 2018.

5 Roland Barthes, Mythologies. (New York: Hill \& Wang. 1983), 110.

$$
\text { JURNAL LISAN AL-HAL } \mid 101
$$


betawi. Hal ini, untuk mengetahui pandangan apa saja yang berbeda dari sudut pandang yang berbeda. Dan yang pasti, keunikan dari penelitian ini yakni pembaca bisa mengetahui bagaimana pandangan dan pemikiran yang dipikirkan dari para barongan atau mengisi ondel ondel yang sering berkeliling di daerah Jakarta.

\section{B. Mitos Kebudayaan Ondel-Ondel}

Menurut Koentjaraningrat kebudayaan (dalam arti kesenian) adalah ciptaan dari segala pikiran dan perilaku manusia yang fungsional, estetis, dan indah, sehingga ia dapat dinikmati dengan pancainderanya (yaitu penglihatan, pennciuman, pengecap, perasa, dan pendengar). Berdasarkan indera penglihatan manusia, maka kesenian dapat dibagi sebagai berikut: seni rupa dan seni pertunjukan. Dalam seni pertunjukan, indera pendengaran sebenarnya juga turut berperan, oleh karena didalamnya diolah pula berbagai efek suara dan musik untuk menghidupkan suasana. Kebudayaan adalah proses belajar, maka memerlukan sebuah media dalam perwujudannya. Media terpenting dalam perwujudan kebudayaan adalah bahasa dan kesenian yang bisa mempresentasikannya secara langsung. Bahasa dalam hal ini bukanlah menjadi ujung tombak, karena ia hanya berfungsi sebagai alat komunikasi yang dipergunakan sehari-hari.Kesenian yang merupakan ungkapan ide atau pikiran dan dapat menunjukan identitas kebudayaan daerah adalah ujung tombaknya. ${ }^{6}$ Kebudayaan Betawi yang hidup dikota metropolitan, sangat besar resikonya untuk luntur dari keberadaan semestinya. Dengan banyaknya ekspansi yang terjadi di Jakarta, ia menjadi tersingkir oleh adanya hal tersebut. Karena keheterogenan penduduk Jakarta saat ini, $\pm 85 \%$ penduduk Jakarta adalah kaum urban. ${ }^{7}$

Ondel-ondel berbentuk boneka besar dengan rangka anyaman bambu dengan ukuran kurang lebih 2,5 m, tinggi dan garis tengahnya kurang dari $80 \mathrm{~cm}$. dibuat sedemikian rupa agar pemikulnya yang berada di dalamnya dapat bergerak dengan leluasa. Rambutnya terbuat dari ijuk, atau "duk" dalam bahasa Betawi. Wajahnya berbentuk topeng atau kedok dengan mata bulat melotot. Ondel-ondel yang menggambarkan lakilaki berwajah merah dan ondel-ondel perempuan berwajah putih atau kuning. Kesenian

${ }^{6}$ Koentjaraningrat, kebudayaan mentalitas dan pembangunan,112-113

${ }^{7}$ Jakarta Dalam angka 1996

$102 \mid$ JURNAL LISAN AL-HAL 
ondel-ondel telah ada sebelum Islam tersebar di Pulau Jawa. Para SenimanBetawi memperkirakan kesenian ondel-ondel telah ada di Jakarta sejak berabad lalu. Istilah ondel-ondel tidak diketahui pasti asal mulanya. Namun apabila ditelaah lebih dalam, besar kemungkinan istilah ondelondel muncul dikarenakan permainan kata semata, dimana muncul pengulangan kata "Ondel" menjadi "Ondel-ondel" dikarenakan ingin menyebut sepasang boneka raksasa itu secara berpasangan, serta juga fitrahnya orang Betawi yang terkenal dengan gaya bicara yang ceplasceplos, tetapi tanpa makna yang jelas ${ }^{8}$. Pada era tahun 40-an kesenian ondel-ondel berperan sebagai leluhur atau nenek moyang yang senantiasa menjaga anak cucunya atau sosial suatu desa dan personifikasi leluhur sebagai pelindung9.

Pola pemikiran masyarakat dulu yang masih percaya terhadap hal-hal yang berbau mistis membuat boneka ondel-ondel dijadikan media perantara untuk para roh-roh nenek moyang. Dikarenakan waktu yang sangat mendesak, pembuatan Barongan pada saat itu menjadi sangat seadanya, bermodalkan kayu dan rotan serta kain bekas/kain perca yang tak lagi terpakai dan juga menyeramkan (khusus untuk barongan lakilaki), hal itu ditandai dengan adanya gigi taring pada barongan laki-laki pada masa-masa awal, yang tak lagi kita temui pada kesenian ondel-ondel modern. Setelah barongan selesai dibuat, maka diadakan ritual atau ngungkup (penguapan dan pembakaran kemenyan pada bagian dalam kerangka barongan). Selepas itu barongan mulai banyak digunakan dalam upacara penolakan bala lainnya, seperti upacara peletakan batu pertama hingga upacara peresmian gedung/bangunan baru.

Oleh karena itu tidak heran kalau wujud ondel-ondel dahulu, menyeramkan. Hingga pada zaman pemerintahan Gubernur Ali Sadikin pada tahun 1966 - 1977 ondel-ondel mulai diangkat sebagai kesenian rakyat. Tentu saja tampilanya belum semenarik sekarang. Semenjak dijadikan kesenian daerah sedikit demi sedikit wajah ondel-ondel mulai "dimanusiakan" atau dimodifikasi hingga dengan tampilan pada saat ini

8 Dewanti, A. R. Ondel-ondel sebagai ikon seni tradisi Betawi. Prosiding Seminar Nasional Seni Tradisi Keragaman Tradisi Sebagai Warisan Budaya , 208-215. Retrieved from http://libprint.trisakti.ac.id/9/1/PROSIDING_A_Asih.pdf. 2014.

${ }^{9}$ Faizah, N., Zid, M., \& Ode, S. H. Mobilitas sosial dan identitas etnis Betawi (Studi terhadap perubahan fungsi dan pola persebaran kesenian ondel-ondel di DKI Jakarta). Jurnal Spatial: Wahana Komunikasi Dan Informasi Geografi, 18(1), 36-50. Retrieved from http://journal.unj.ac.id/unj/index.php/spatial/article/download/7423/5311. 2018.

\begin{tabular}{l|l} 
JURNAL LISAN AL-HAL & 103
\end{tabular} 
yang cantik dan juga tampan. Ketika melakukan pertunjukan, dengan dengan menggoyang-goyangkan badan dan kepala yang menoleh ke kiri dan ke kanan, ondel-ondel sering kali diiringi dengan musik khas Betawi seperti tanjidor.

Selain diiringi tanjidor dan marawis, ondel-ondel juga sering diiringi dengan gambang kromong, yaitu kelompok musik khas Betawi yang juga sering dipakai untuk mengiringi acara Lenong Betawi, serta diiringi juga dengan tari-tarian (umumnya silat, dibawakan oleh dua orang pria). Ketika wajah kota Jakarta berubah menjadi lebih modern sekitar tahun 1960-an hingga kini, wajah boneka raksasa itu tampilannya tidak lagi menyeramkan dan berbau mistis. Wajah dan gambaran dari ondelondel masa kini tampak lebih manis dan bersahabat bagi semua semua kalangan, termasuk anakanak. Ondel-ondel yang dahulu telah mengalami reproduksi budaya yang mempunyai bentuk dan fungsi yang berbeda dengan saat ini. Hal itu agar ondel-ondel dapat diterima oleh masyarakat Kota Jakarta pada umumnya yang mempunyai kebudayaan dan latar belakang yang berbeda.

Sejak tahun 1977, ondel-ondel terlihat lebih bersifat kebudayaan yang menghibur untuk acara seremonial orang Betawi, seperti khitanan, pernikahan, dan hajatan-hajatan orang Betawi lainnya. Ondel-ondel juga digunakan sebagai salah satu ikon Kota Jakarta. Dalam perkembangan ondel-ondel, ondel-ondel zaman sekarang masih ada dan menjadi penghias dari Kota Jakarta. Bahkan, sampul ondel-ondel digunakan sebagai sampul buku atau majalah dan cinderamata khas Kota Jakarta.Pada era 40-an, ondel-ondel berfungsi sebagai pengusir setan dan penolak bala oleh sebagian masyarakat Betawi. Kesenian ondel-ondel juga memerankan leluhur atau nenek moyang yang senantiasa menjaga anak cucunya atau sosial suatu desa. Karena pada awalnya berfungsi sebagai personifikasi leluhur sebagi pelindung.

Namun, fungsi tersebut kini telah memudar seiring dengan kemajuan pemikiran masyarakat Betawi. Makna mistis tersebut bertahan hingga pada era 50-an. Ketika itu ondel-ondel tampil dengan rambut gondrong, bercaling, dan menakutkan. Pada era 70-an fungsi ondel-ondel mengalami pergeseran, yakni sebagai pengarak atau pengiring pengantin sunat gaya Betawi. Pada era ini cara berpakaian ondel-ondel pun mengalami perubahan, terlihat lebih sopan, berwarna, dan bersifat menghibur. Tak hanya itu, ondel-ondel juga telah menjadi salah satu 
simbol Kota Jakarta, misalnya pada perayaan HUT Jakarta dan Festival Palang Pintu. Festival Palang Pintu yaitu salah satu prosesi adat Betawi yang diadakan pada saat upacara penyambutan calon mempelai pria ke kediaman calon mempelai wanita dengan cara saling bersautan pantun, beradu silat dan mengaji yang bertujuan sebagai ujian bagi mempelai pria sebelum diterima sebagai calon suami yang akan menjadi pelindung bagi mempelai wanita.

Model barungan menjadi model awal terbentuknya model ondelondel lainnya. Barungan muncul ketika berbarengan dengan keyakinan bahwa sesuatu yang besar dianggap mempunyai kekuatan untuk melindungi dan melawan kejahatan (pengaruh animisme dan dinamisme di mana benda memiliki ruh dan kekuatan nenek moyang). Bentuknya yang sederhana disebabkan adanya kebutuhan mendesak dalam menanggulangi wabah penyakit menular pada saat itu. Barungan dijadikan perwujudan leluhur penjaga kampung ${ }^{10}$.

Berdasarkan visual yang ada, ukuran tubuh barungan 2x lebih tinggi manusia pada umumnya. Bagian kepalanya seperti memiliki rambut dan hiasan kepala berupa mahkota dikelilingi oleh kembang kelapa. Menurut Saputra, kadangkala ditambahkan daun kemuning karena memiliki wangi yang harum dengan penempatan tidak beraturan. Dahulu kembang kelapa dipercaya sebagai penolak bala. Saat pertunjukan usai, penonton memerbutkan kembang kelapa untuk diletakan di atas pintu rumah, sebagai penolak bala. Wajah barungan menyeramkan, mata bulat melotot dengan taring panjang melengkung keluar, dan berdaun telinga lebar.

Gambar 2. Barongan, 1923

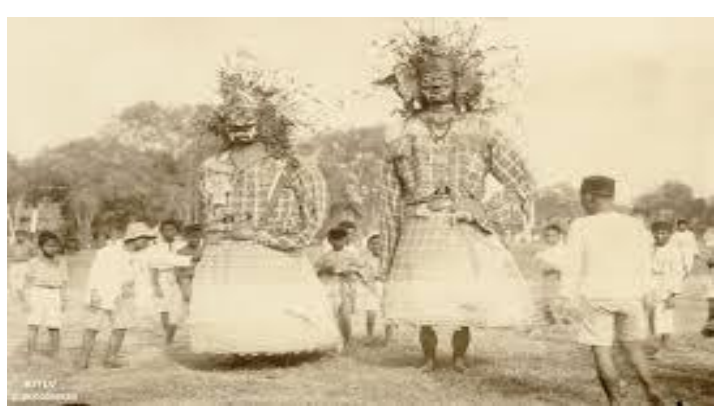

10 Design, G., Program, N. M., \& Departmen, F. A. (n.d.). Membaca Perubahan Tanda Visual dan Makna pada Ondel-ondel dalam Perkembangan Masyarakat Betawi. JURNAL LISAN AL-HAL $\mid 105$ 
Pada era tahun 40-an kesenian ondelondel berperan sebagai leluhur atau nenek moyang yang senantiasa menjaga anak cucunya atau sosial suatu desa dan personifikasi leluhur sebagai pelindung. Pola pemikiran masyarakat dulu yang masih percaya terhadap hal-hal yang berbau mistis membuat boneka ondel-ondel dijadikan media perantara untuk para roh-roh nenek moyang. Dikarenakan waktu yang sangat mendesak, pembuatan Barongan pada saat itu menjadi sangat seadanya, bermodalkan kayu dan rotan serta kain bekas/kain perca yang tak lagi terpakai dan juga menyeramkan (khusus untuk barongan laki-laki), hal itu ditandai dengan adanya gigi taring pada barongan laki-laki pada masamasa awal, yang tak lagi kita temui pada kesenian ondel-ondel modern. Setelah barongan selesai dibuat, maka diadakan ritual atau ngungkup (penguapan dan pembakaran kemenyan pada bagian dalam kerangka barongan). Selepas itu barongan mulai banyak digunakan dalam upacara penolakan bala lainnya, seperti upacara peletakan batu pertama hingga upacara peresmian gedung/bangunan baru. Oleh karena itu tidak heran kalau wujud ondel-ondel dahulu, menyeramkan.

\section{Perspektif Psikologi Ulayat Tentang Kepercayaan Terhadap Mitos Kebudayaan.}

Rupanya, memercayai mitos dan takhayul tidak hanya ekslusif di antaran orang Indonesia saja. Menurut survei terbaru, tiga perempat orang Amerika juga masih banyak yang percaya pada paranormal. Bahkan, satu dari lima orang Amerika mengaku pernah melihat hantu. Hal ini mendorong para psikolog untuk menguraikan alasan di balik kejadian paranormal. Seperti dilansir dari BBC, para psikolog berkata bahwa beberapa manusia memang tidak dapat melepaskan diri dari takhayul dan cerita rakyat lama. Saat manusia memercayai hal semacam itu, timbul perasaan yang menguntungkan dan seseorang memiliki cukup alasan untuk memahami suatu kejadian. Pasalnya, otak manusia memang selalu berusaha mencari jawaban dan makna di balik peristiwa.

Tapani Riekki, psikolog dari Universitas Helsinki di Finlandia, mencoba untuk menjelaskanya berdasarkan penelitian selama beberapa tahun terakhir. Riekki meneliti dua kelompok orang terkait pandangannya terhadap paranormal, yakni orang yang skeptis dan orang yang percaya paranormal. Kedua kelompok diminta untuk melihat animasi bentuk 
gerakan sederhana. Ternyata, orang yang percaya paranormal lebih cenderung melihat semacam niat di balik gerakan, dan ini tercermin dalam aktivitas otak yang lebih besar yang berkaitan dengan teori pemikiran dan memahami motif orang lain. Orang yang percaya takhayul juga cenderung melihat wajah-wajah tersembunyi dalam foto sehari-hari. Temuan ini dikonfirmasi oleh tim lain di Universitas Amsterdam yang menemukan bahwa orang yang percaya paranormal cenderung melihat ada sosok yang berjalan di dalam cahaya.

Selain itu, orang yang memercayai paranormal memiliki penghambat kognitif yang lebih lemah dibandingkan dengan orang yang skeptis. Kemampuan ini membantu orang-orang skeptis untuk menyingkirkan pikiran yang tidak diinginkan. Sementara itu, makalah lain juga melaporkan bahwa orang yang percaya takhayul cenderung punya kepercayaan diri yang lebih besar dalam membuat keputusan. Hal ini membuat mereka tidak mudah melepaskan apa yang telah dipercaya. Meski demikian, rupanya memercayai paranormal tidak selalu negatif. Percobaan lain menunjukkan bahwa berbagai kepercayaan takhayul dapat meningkatkan kinerja dan keterampilan.

Hanya dengan memakai pakaian atau membawa benda yang dianggap beruntung untuk menghadapi ujian, performa Anda bisa menjadi lebih baik. Sebab, hal ini dapat meningkatkan kepercayaan pada kemampuan diri. Ciri Mitos adalah mentranformasikan makna ke dalam bentuk (form), oleh karena itu mitos selalu sebuah pencurian bahasa ${ }^{11}$. Fokus pencurian tidak terhadap bahasa itu sendiri tetapi terhadap bentuk. Arnold Hauser menyatakan bahwa kelahiran sebuah gaya artistik dimulai dari ide individual, personal, kreatif. Dalam kaitan dengan model ondelondel barongan, ide tersebut bisa diwujudkan karena cocok dengan kebijakan yang digariskan oleh penguasa. Dalam hal ini terjadi dialektika dan menurut Hauser proses dialektika muncul paling cepat melalui perkembangan sebuah gaya seni ${ }^{12}$. Pada saat model barongan dibuat karena adanya desakan kepentingan menangkal penyakit menular maka penampilan barongan sangat sederhana, menggunakan bahan-bahan alam yang ada di sekitar masyarakat ditambah dengan kepercayaan bahwa benda-benda besar memiliki roh dan kekuatan gaib untuk melindungi masyarakat sekitar.

${ }^{11}$ Roland Barthes, Mythologies. (New York: Hill \& Wang. 1983), 131.

12 Hauser, Arnold. The Sosiology of Art. (New York: Routledge. 1982), 408. 
Bentuk barongan sebagai karya seni yang terjadi merupakan hasil dari tawar menawar antara pemerintahan Belanda saat itu dengan kebutuhan dan kepercayaan masyarakat Betawi (konstruksi mental). Ondel-ondel merupakan bentuk tradisi kebudayaan yang unik di Jakarta, namun belum banyak studi yang berfokus padaperspektif psikologisnya, khususnya dalam aspek kepercayaan mitosnya. Dalam kebudayaan ondelondel,sebagai cara untuk penolak bala atau nasib buruk menurut kepercayaan orang zaman dahulu. Dalam lingkungan zaman saat ini, peneliti menduga adanya pergeseran makna kepercayaan mitos terhadap kebudayaan ondel-ondel. Namun, hasil penelitian ini menunjukkan bahwa adanya pergeseran makna mitos kebudayaan ondel-ondel pada masyarakat zaman sekarang dibandingkan dengan zaman dahulu.

\section{Metode}

Metode penelitian ini menggunakan metode penelitian kualitatif. Dan mengambil data dengan wawancara, obseervasi dan analisis berbagai jurnal atau studi pustaka. Metode wawancara menggunakan metode semi Terstruktur dan wawancara dilakukan dengan tatap muka.

\section{E. Hasil dan Pembahasan}

\section{Perbedaan Makna Kepercayaan Masyarakat Jakarta Saat Ini dan} Zaman Dahulu terhadap Mitos Kebudayaan Ondel-Ondel.

Ondel-ondel yang menggambarkan laki-laki memiliki wajah berwarna merah, sedangkan untuk yang menggambarkan perempuan memiliki wajah berwarna putih atau kuning. Pada jaman dulu ondel-ondel biasanya digunakan untuk memeriahkan arak-arakan, seperti mengarak pengantin sunat dan sebagainya. Pada umumnya dibawa sepasang, yaitu laki-laki dan perempuan. Bahkan dalam perayaan-perayaan umum seperti ulang tahun kota Jakarta, biasanya dibawa juga beberapa pasang untuk memeriahkan acara tersebut.Awal mulanya ondel-ondel berfungsi sebagai penolak bala atau gangguan roh halus yang gentayangan. Namun saat iniondel-ondel biasanya digunakan untuk menambah semarak pesta-pesta rakyat atau untuk penyambutan tamu terhormat, misalnya pada peresmian gedung yang baru selesai dibangun bahkan dijadikan sebagai bahan tontonan masyarakat untuk mendapatkan saweran.

Pada saat ini pembuatan dan pertunjukkan ondel-ondel oleh masyarakat Betawi modern, tidak lagi memerlukan sesajen sebagai syarat 
persembahan untuk mendapatkan kekuatan saat memainkan ondelondel.Musik pengiring yang dilakukan untuk ondel-ondel tidak sama, tergantung tiap masing-masing rombongan. Ada yang diiringi tanjidor, ada yang diiringi gendang pencak. Adapula yang diiringi instrumen lagu daerah Betawi. Ondel-ondel juga dikaitkan dengan ritual yang dijalankan oleh nenek moyang untuk menolak bala yang dikenal dengan tradisi barungan, yaitu kegiatan rombongan arak-arakan keliling kampung boneka besar yang diiringi musik (tabuh, tek yan).

Jenis pertunjukan ondelondel sudah ada sebelum tersebarnya agama Islam di Jawa. Awal mula masyarakat Betawi menyebutnya dengan barongan yang berasal dari kata barengan atau bareng-bareng. Sebutan itu datang dari kalimat ajakan dalam logat Betawi Benyamin Sueb (alm.) melantunkan tembang ondel-ondel. Bagaimanapun, Benyamin tidak bermaksud mengubah sebutan boneka Betawi itu. Namun setelah laris terjual di pasaran, sejurus dengan itu, sebutan barongan pun tergeser oleh ondel-ondel. Ondel-ondel adalah salah satu kesenian Betawi yang dulu bersifat magis, tampak dari penggunaan mantra-mantra serta kepercayaan untuk berkomunikasi dengan arwah nenek moyang karena tidak sembarang orang dapat melainkan ondel-ondel apalagi membuatnya.

Pelaksanaan pertunjukan tersebut dilengkapi dengan beberapa cara, antara lain menghidangkan sesaji. Pada era 40-an ondel-ondel berperan sebagai leluhur atau nenek moyang yang senantiasa menjaga anak cucunya atau sosial suatu desa dan personifikasi leluhur sebagai pelindung. Pola pemikiran masyarakat dulu yang masih percaya terhadap hal-hal yang berbau mistis membuat boneka ondel-ondel dijadikan media perantara untuk para roh-roh nenek moyang. Makna mistis bernuansa sakral dan keramat berkembang hanya pada tahun 70-an dalam kehidupan masyarakat Betawi. Ondel-ondel yang diekspresikan dalam bentuk topeng orang-orangan besar, yang dalam pertunjukannya menarinari dan menggoyangkan kepalanya yang digerakkan oleh seseorang dalam topeng itu sendiri.

Pada era ini Ondel-ondel juga telah menjadi salah satu simbol Kota Jakarta, misalnya pada perayaan HUT Jakarta dan Festival Palang Pintu. Festival Palang Pintu yaitu salah satu prosesi adat Betawi yang diadakan pada saat upacara penyambutan calon mempelai pria ke kediaman calon mempelai wanita dengan cara saling bersautan pantun atau pun dalam

$$
\begin{array}{l|l}
\text { JURNAL LISAN AL-HAL } & 109
\end{array}
$$


acara khitanan. Namun, seiring dengan berkembangnya Ondel-ondel, banyak oknum-oknum yang tidak bertanggung jawab yang memanfaatkan kesenian Betawi ini. Tidak jarang kita melihat banyak Ondel-ondel yang turun ke jalan untuk mengamen. Hal tersebut membuat adanya perubahan fungsi dari Ondel-ondel itu sendiri. Berdasarkan hasil wawancara dengan 3 orang subjek yang menuturkan bahwa Ondel-ondel sekarang hanya untuk hiburan dan alat untuk mencari uang. Awal mula Ondel-ondel dianggap sesuatu yang sakral dan dihargai, kini telah bergeser menjadi suatu alat untuk memenuhi kebutuhan hidup dengan cara mengamen. Banyak pihak yang menyayangkan dan tidak setuju apabila aset kebudayaan harus turun ke jalan karna dampaknya berpengaruh terhadap nilai budaya Betawi, ditambah dengan banyaknya pengamen Ondel-ondel yang mengamen tanpa menggunakan musik pengiring. Secara tidak langsung, dengan adanya perubahan fungsi dari Ondel-ondel menjadi alat untuk mencari makan, maka berubah pula maknadari Ondel-ondel itu sendiri.

Perkembangan industri dan bisnis hiburan telah mengubah pandangan masyarakat terhadap fungsi dan makna kesenian ini. Kesenian tradisional Ondel-ondel telah diangkat dan dikembangkan sebagai suatu kesenian yang popular dikalangan masyarakat umum di kota besar Jakarta, yang dianggap sebagai kesenian milik masyarakat Betawi, yang kini telah menjadi kesenian "modern" yang setara dengan keseniankesenian modern lainnya. Terlihat dalam masyarakat Betawi sendiri dengan adanya usaha atau kreatifitas masyarakat Betawi untuk mengangkat dan mempopulerkan kesenian tradisional menjadi "kesenian populer". Namun, pada abad ke 21 ini mungkin ada beberapa kesenian Betawi yang hilang karena gagalnya dalam pewarisan kesenian tersebut. Kemajuan kesenian Betawi ini tidak lepas dari peran para seniman dalam menjaga eksistensi Ondel-ondel Betawi.

Semakin tinggi eksistensi Ondel-ondel, semakin marak pula oknum yang memanfaatkan kesenian ini untuk meraih keuntungan pribadi tanpa mengikuti pakem yang berlaku. Perubahan pada fungsi Ondel-ondel yang mengakibatkan penurunan makna dan nilai, tidak mempengaruhi terhadap minat masyarakat kepada pertunjukan Ondel-ondel. Mereka pun tidak segan untuk melibatkan dan menyewa Ondel-ondel dalam acara khitanan, pernikahan, maupun acara ulang tahun yang bersifat untuk menghibur masyarakat sekitar. Perkembangan ondel-ondel ini tidak 
sesuai dengan keadaannya dilapangan. Banyak ondel-ondel yang dimanfaatkan oleh oknumoknum liar untuk turun ke jalan sebagai pengamen atau hanya sekedar meminta belas kasihan dari pengguna jalan. Awal mula ondelondel turun ke jalan adalah untuk mengenalkan kesenian Betawi ini kepada masyarakat, namun niat baik ini disalahgunakan sebagian orang. Ondel-ondel ini dijadikan alat untuk mencari makan karena tergiurnya dengan pendapatan dari mengamen ondel-ondel setiap harinya.

Dalam satu hari mengamen para pelakon Ondel-ondel ini bisa mendapatkan uang sekitar 300.000 - 500.000 dan itu belum dipotong uang sewa sekitar 50.000 - 70.000 serta dibagi rata kesemua pemain. Para pelakon ondel-ondel hanya perlu sebuah ondel-ondel yang dapat mereka sewa atau mereka buat sendiri dengan alat seadanya. Bentuk ondel-ondel itu pun tidak diperhatikan sesuai dengan pakem yang berlaku. Ondelondel liar hanya menggunakan plastik hitam sebagai pengganti rambut ondel-ondel yang seharusnya terbuat dari ijuk. Ukuran wajah atau topeng tidak disesuaikan dengan ukuran tubuh dari ondel-ondel tersebut, sehingga terjadi kesenjangan antara ukuran wajah dengan ukuran badan. Serta pakaiannya yang dikenakan ondel-ondel liar terkesan sangat lusuh dan kotor karena tidak adanya kepedulian pelakon ondel-ondel tersebut terhadap penampilan alat kebudayaan yang dibawakannya. Selain penampilan yang kurang menarik dan tidak sesuai dengan pakem kesenian ondel-ondel, pertunjukannya pun tidak diiringi dengan musik tabuhan ondel-ondel, baik secara live maupun dengan kaset, dan lagu yang dibawakan merupakan bukan lagu-lagu Betawi, melainkan lagu barat ataupun lagu dangdut. Para pelakon hanya membawa ember kecil untuk sekedar meminta uang kepada masyarakat yang ditemuinya.

Kepercayaan spiritual pada kebudayaan ondel-ondel berkaitan dengan jurnal penelitian telah hadir suatu mazhab psikologi Transpersonal yang dalam banyak hal mendasar berbeda dengan ketiga mazhab sebelumnya. Atas kritik dan penyem-purnaan terhadap mazhabmazhab psikologi sebelumnya, psikologi transpersonal lahir sebagai kelanjutan dari psikologi humanistik dan dapat dikatakan menjadi mazhab keempat dalam dunia psikologi. Psikologi transpersonal berusaha untuk menggabungkan tradisi psikologis dengan tradisi agama-agama besar dunia. Ia ingin men-guak pesan terdalam dari semangat agama yang sering dilupakan-bahkan oleh pemeluknya sendiri, yaitu sophia perennis. Bila 
ditelusuri alur sejarah lahirnya aliran ini, pada dasarnya ia hadir diprakarsai oleh tokoh-tokoh psikologi yang prihatin terhadap kondisi masyarakat Barat modern waktu itu yang hidup dalam gelimang materi tetapi miskin secara spiritual. Dapat disebutkan disini misalnya Anthony Sutich (1907-1976), pendiri The Journal of Humanistic Psychology, sebagai pendiri mazhab psikologi transpersonal. Ia mengumpulkan tokohtokoh yang punya paham yang sama di rumahnya di California. Mereka membahas secara informal topik-topik yang tidak diperhatikan oleh psikologi hu-manistik dan gerakan potensi manusia waktu itu.

Pertemuan itu dihadiri antara lain, Abraham Maslow (1908-1970), tokoh psikologi humanistik yang mempopulerkan peak experience (pengalaman puncak). Diskusi berlangsung sangat menarik, bukan karena topik yang dibicarakan sangat beragam, melainkan karena Sutich yang memimpin diskusi dalam kondisi berbaring akibat serangan pe-nyakit kronis. Ia memimpin diskusi dengan menggunakan cermin diatas kepalanya. Stanislav Grof (1931), Maslow, dan Victor Frankl (1905-1997) kemudian mengusulkan istilah transpersonal bagi gera-kan psikologi yang mereka rintis. Seperti halnya psikologi humanistik, psikologi transpersonal juga menaruh perhatian pada dimensi spiritual manusia, hanya bedanya adalah kalau psikologi humanistik lebih memanfaatkan potensi-potensi ini untuk peningkatan hubungan antar manusia, sedangkan psikologi transpersonal lebih tertarik untuk meneliti pengalaman subjektif-transendental, serta pengalaman luar biasa dari potensi spiritual manusia ini.

Gambaran selintas tentang psikologi transpersonal ini menunjukkan bahwa aliran ini mencoba untuk menjajagi dan melakukan telaah ilmiah terhadap suatu dimensi yang sejauh ini lebih dianggap sebagai bidang garapan kaum kebatinan, ruhaniawan, agamawan, dan mistikus. Sekalipun masih dalam taraf telaah awal, Psikologi transpersonal menunjukkan bahwa di luar alam kesadaran biasa terdapat ragam dimensi lain yang luar biasa potensialnya. Dari paparan di atas dapat dipahami, bahwa dalam perspektif aliran ini, struktur kepribadian manusia tidaknya terdiri unsur fisik ataupun psikhis semata, tapi juga mengandung unsur spiritual. Dan dari Tri determinan; raga, psikis dan spiritual yang eksis dalam diri manusia, dimensi spirituallah yang merupakan dimensi pembeda antara manusia dengan makhluk-makhluk lainnya. Dimensi ini bukan terletak dalam alam tak sadar dalam artian konvensional- 
psikoanalisis, melainkan bertempat di atas sadar, dalam artian supraconsciousness, yang merupakan kelanjutan dari alam sadar (the consciousness), menurut istilah psikhoanalisis. Dimensi spiritual ini, dalam perspektif salah satu tokoh aliran psikologi transpersonal, Viktor E. Frankl, mengejawantah ke alam sadar dan benar-benar dapat dialami dan disadari manusia, meskipun bagi sebagian besar masih belum teraktualisasi atau masih merupakan potensialitas yang tidak disadari.

Namun sekalipun dimensi ini semula "terletak" di alam tak sadar, tetapi tidak sama dan tidak ada hubungannya dengan insting-insting primer yang juga "tersimpan" dalam alam tak sadar. Sebuah pandangan yang cukup revolusioner mengenai manusia dan kesadarannya. Meski tidak diragukan bahwa aliran ini sering menyebut dan mengakui adanya daya spiritual dalam struktur kepribadian manusia, namun spiritual yang dimaksud disini bukanlah agama, tetapi sebatas pada ketergantungan manusia pada sesuatu yang belum atau tidak realistik. Sebagaimana ungkapan Frankl, bahwa maksud spiritual yang ia maksud tidak mengandung arti agama. Spiritual diartikan sebagai inti kemanusiaan dan sebagai sumber makna hidup dan potensi dari berbagai kemampuan dan sifat luhur manusia yang luar biasa. Spiritual dalam perspektif aliran ini hanyalah aspirasi manusia untuk hidup bermakna, dan sumber dari kualitas-kualitas insani.

Berdasarkan hasil wawancara dengan 4 narasumber warga yang berada di wilayah Jakarta, sebagai berikut:

1. Nama : syifa hanifah

Jenis kelamin : perempuan

Usia : 19 tahun

Pekerjaan : mahasiswi keturunan betawi asli

Berdasarkan hasil keterangan yang kami dapatkan melalui wawancara, ondel-ondel pada zaman dahulu digunakan sebagi penolak bala supaya orang rumah tidak terkena gangguan yang bersifat ghaib. Perbedaannya kalau zaman sekarang orang-orang sudah tidak terlalu percaya tentang penolak bala, berbeda dengan saat ini ondel-ondel dibuat sebagai hiburan. Bahkan ada juga yang dibuat sebagai alat mencari uang. Narasumber merasa agak kecewa ondel-ondel dibuat untuk 'mengemis' karena ondel-ondel ini budaya, cara melestarikannya harusnya tidak seperti itu. Seharusnya ondel-ondel digunakan saat ada acara besar kalau dibuat mengemis membuat citra ondel-ondel hilang. Semoga pemerintah 
dapat membuat kebijakan tentang penggunaan ondel-ondel ini. Pesan narasumber untuk masyarakat betawi "ayo jaga dan lestarikan budaya kita, jangan sampai saat budaya kita hilang atau dirusak kita baru marahmarah. Jaga selagi ada."

2. Nama narasumber: Rudi

Jenis kelamin: Laki-Laki

Usia: 22 Tahun

Pekerjaan : tukang ondel-ondel keliling

Narasumber merupakan bukan asli dari Jakarta, melainkan narasumber adalah pendatang yakni berasal dari Tegal, dan baru tinggal di Jakarta setahun yang lalu, namun narasumber sudah terbiasa dan bisa beradaptasi dengan lingkungan Jakarta. Lalu narasumber biasanya berkeliling ondel ondel dari Pulo Gadung ke daerah Cilincing dengan membawa ondel ondel berjalan berama dengan partner nya secara bergantian.

Narasumber sebenarnya tidak mengerti dan tidak paham mengenai mitos atau asal usul perihal ondel ondel secara khusus, narasumber haya mengetahui sedikit bahwa pada zaman dahulu ondel ondel memiliki nilai mistis yang mana yang berhubungan dengan makhluk halus. Lalu, narasumber menjelaskan bahwa pendapatan narasumber dari berkeliling ondel ondel sebesar 90 ribu sampai 100 ribu saja perhari. Dan jika pada hari hari besar, mendapatkan lebih dari pendapatan biasanya. Biasanya berkeliling mulai dari jam 4 sore, istirahat pada saat maghrib, lalu dilanjut sampai jam 9 malam. Tanggapan narasumber perihal pemprov DKI Jakarta, narasumber mengatakan bahwa satpol PP sudah memberikan ketentuan untuk ondel ondel bisa beroprasi lagi. Yaitu, ketika sedang berkeliling, harus tetap memakai masker dan berjaga jarak dengan masyarakat atau orang lain dan ketika sedang berlekliling harus ada alat gendang pengiring musiknya, tidak boleh cuman alat sound system saja. Ketika sedang berkeliling, hambatan yang di alami adalah bertemu dengan borongan, ketika berpapasan dengan borongan, selalu ribut dan bertengkar adu mulut dengan borongan, jadi hal itu yang membuat nilai masyarakat betawi jadi jelek dan tercemar. Narasumber menjelaskan bahwa ondel ondel yang diapakai untuk berkeliling tersebut beliau beli dan tidak membuatnya karena tidak mengeti bagaimana cara mebuat ondel ondelnya. Langsung dipakai untuk berkeliling.

3. Nama : H. zaenudin

114 JURNAL LISAN AL-HAL 
Jenis kelamin : laki-laki

Usia $\quad: 53$ tahun

Pekerjaan : Tokoh masyarakat betawi di wilayah Jakarta utara

Menurut keterangan dari hasil wawancara, ondel-ondel erat kaitannya dengan budaya betawi. Karena orang betawi itu menurut pandangan narasumber sangatlah demokratis. Suku yang tidak punya raja yakni dari jaman dahulu hidup demokrasi merakyat apa adanya. Sesuai dengan karakter kebudayaan yang campuran baik dari budaya nya maupun orang-orang nya. Terdiri dari etnis eropa,cina, dan arab. Kalau dari pakaian ondel-ondel erat dari kebudayaan cina dan suku melayu. Suku melayu yang ada di Kalimantan pun mirip-mirip dengan corak pakaian ondel-ondel. Ondel-ondel pada zaman dahulu atau disebut juga dengan barongan dipakai pada saat-saat tertentu seperti ketika ada hajatan, tidak sembarang hari ada ondel-ondel. Ketika akan memanen padi atau acara pernikahan bahkan sunatan dengan musik yang khas. Sangat berbeda jauh dengan zaman sekarang yang sedang viral, ondel-ondel berkeliling setiap hari di Jakarta. Karena diambil sebagai konsumtif, ladang mencari uang belaka. Pada zaman dulu terdapat ciri khas rancah seperti silat-silat pada pertunukan ondel-ondel. Di sekelilingnya biasanya ada 4-5 orang. Sayangnya kebudayaan tersebut telah habis kemakan zaman.narasumber berharap pemprov Jakarta bisa lebih menertibkan budaya ondel-ondel yang sudah dimarginalkan para pendatang dari luar Jakarta. Walaupun pemerintah sudah member wadah seperti ormas kebudaayan betawi, kerja sama masyarakat Jakarta juga diperlukan. Untuk masyarakat betawi seyogyanya untuk peduli dan gali lagi untuk kesempatan seperti untuk buat karya ilmiah asal-muasal dan kenapa bisa terjadi terutama untuk anak muda betawi. Di satu sisi subjek merasa malu, tetapi membingngkan juga bagaimana untuk mengembalikan makna kebudayaan betawi pada zaman dahulu.

4. Nama : Nur Farras Nabila syafiah

Jenis kelamin : Perempuan

Usia $\quad: 20$ tahun

Pekerjaan : Mahasiswi keturunan betawi asli

Menurut pandangan narasumber mengenai budaya ondel ondel pada zaman dahulu yaitu dari yang dilihat pada zaman waktu ia kecil, ondel-ondel di gunakan sebagai icon kota jakarta, khususnya masyarakat betawi(asli jakarta). Biasanya, ondel-ondel di gunakan untuk acara besar 
seperti pernikahan, sunatan ataupun pesta rakyat. Ondel-ondel akan di taruh di depan rumah orang yang punya hajat acara itu sebagai icon warga betawi, adapun untuk pesta rakyat seperti ulang tahun jakarta atau lainnya itu biasanya ondel-ondel akan di arak dengan di iringi lagu betawi.

Lalu mengenai dengan perbedaanya, Beda nya dari zaman sekarang, acara besar seperti pesta rakyat sudah jarang sekali mengiringi ondel-ondel, dan pada zaman sekarang sering kali kita melihat di pinggiran kota jakarta banyak sekali anak kecil sampai orang dewasa mengiringi ondel-ondel atau yang biasa di sebut pengamen ondel-ondel. Sebenar nya menurut saya tidak apa-apa jika ingin menjadikan ondelondel untuk mendapatkan uang, akan tetapi jangan sampai menghilangkan budaya asli dari ondel-ondel tersebut. Contoh nya seperti lagu untuk mengiringi ondel-ondel seharusnya dengan lagu adat, namun sekarang mengarak ondel-ondel banyak yang di iringi dengan lagu dangdut ataupun lainnya.

Harapan narasumber kepada pemerintah adalah agar dari pemerintah nya sendiri untuk selalu melestarikan budaya jakarta, seperti membuat kampanye tentang budaya jakarta, membuat penyuluhan untuk siswa sekolah dasar tentang budaya jakarta khusunya ondel-ondel, karena banyak sekali anak-anak kecil yang takut dengan ondel-ondel karena bentuk nya yang besar, dan saya harap pemerintah bisa memfasilitasi sanggar budaya di daerah jakarta dan sekitar nya untuk terus berkarya membuat ondel-ondel.

Dan untuk masyarakat betawi, di harapkan tetap menjaga icon ondel-ondel agar jangan sampai punah di lingkungan kita, terus mengenalkan ondel-ondel kepada penerus bangsa agar tetap terjaga nya budaya tersebut. Jika bukan kita(sebagai warga betawi) yang menjaga budaya (ondel-ondel) tersebut, maka siapa lagi yang akan menjaga.

Berdasarkan wawancara pada ke 4 narasumber dan 3 diantaranya adalah masyarakat betawi. Masyarakat Betawi merasa kesal dengan adanya Ondel-ondel ngamen karenamenurut mereka, mencari keuntungan dengan menggunakan budaya yang dimana sudah ditetapkan sebagai ikon suatu daerah adalah hal yang tidak layak untuk dilakukan, namun mereka tidak dapat berbuat apa-apa. Masyarakat Betawi juga merasa prihatin dengan munculnya Ondel-ondelngamen dipinggir jalan, seharusnya kini Ondel-ondel memiliki fungsi sebagai bentuk dari kesenian budaya Betawi, namun karena kurangnya perhatian dan kebutuhan akan ekonomi 
mendesak menjadikan Ondel-ondel turun ke jalan untuk mengamen ${ }^{13}$.

\section{Analisis Keilmuan}

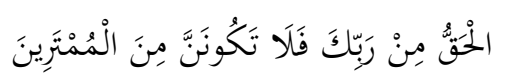

Kebenaran itu adalah dari Rabb-mu, sebab itu janganlah sekali-kali kamu termasuk orang-orang yang ragu. Diantara cara berfikir yang menyimpang dari kebenaran adalah percaya kepada khurafat dan mitos. Yang dimaksud dengan mitos adalahcerita-cerita bohong tentang suatu hal seperti asal-usul tempat, alam, manusia dan sebagainya yang mengandung arti mendalam dan diungkapkan dengan cara gaib. Sedangkan definisi khurafat adalah ajaran atau keyakinan yang tidak mempunyai landasan kebenaran, disebut pula takhayul.

Percaya dan bersandar pada khurafat dan mitos (cerita-cerita bohong) adalah salah satu cara berfikirdan berdalil orang-orang musyrik. Mereka tidak menggunakan akal dan hati mereka untuk mencari dan mengamalkan kebenaran. Dan itu merupakan sebab mereka dimasukan kedalam Neraka. Allah SWT berfirman dalam Al-Qur'an Surat alMulkayat 10:

$$
\text { وَقَالُوا لَوْ كُنَّا نَسْمَعُ أَوْ نَعْقِلُ مَا كُنَّا فِي أَصْحَابِ السَّعِيرِ }
$$

"Dan mereka berkata: Sekiranya kami mendengarkan atau memikirkan (peringatan itu) niscaya tidaklah kami termasuk penghunipenghuni Neraka yang menyala-nyala."

Khurafat dan mitos merupakan salah satu sebab disembahnya patung-patung, batu, benda-benda keramat dan sesembahan lainnya selain Allah SWT. Di Indonesia khususnya, banyak khurafat dan mitos yang hingga saat ini dipercaya sebagai sebuah kebenaran secara turun temurun. Bahkan bukan hanya dipercaya tapi kepercayaan itu direalisasaikan dalam bentuk ritual-ritual tertentu yang mengandung unsur kesyirikan.

Menurut Van Peursen didalam jurnal penelitian mitos adalah suatu cerita yang memberikan pedoman atau arah tertentu pada komunitas masyarakat. Cerita tersebut dapat berbentuk simbol-simbol yang memberi gambaran tentang suatu hal kebaikan dan keburukan, kehidupan dan

${ }^{13}$ Chienita, I., Susanto, E. H., \& Winduwati, S. Persepsi Masyarakat Betawi Terhadap Fenomena Ondel-Ondel Ngamen. Koneksi, 2(2), 380. https://doi.org/10.24912/kn. v2i2.3913. 2019. 
kematian, dosa dan penyucian, perkawinan dan kelahiran, akhirat, surga, dan neraka ${ }^{14}$. Dipandang dari segi keadaan, mitos juga dapat diartikan dengan sesuatu yang erat kaitannya dengan hal-hal mistis di mana manusia merasa terkepung oleh kekuatan-kekuatan ghoib di sekitarnya, yaitu kekuasaan dewa-dewa alam raya atau kekuasaan kesuburan seperti yang trrdapat dalam mitologi primitive ${ }^{15}$. Dalam percakapan sehari-hari, "mitos" mengandung makna kepalsuan. Penyebutan tentang sesuatu sebagai mitos akan mengisyaratkan rendahnya nilai sehingga tidak perlu dipertahankan. Dalam pengertian ini, mitos adalah semakna dengan takhayul (dari bahasa Arab takhayul, yakni pengkhayalan), dongeng atau supertisi. Perkataan Inggris myth adalah dari perkataan Latin myithus atau Yunani mythos. Secara perkamusan, mitos ditakrifkan sebagai penuturan yang khayali belaka, yang biasanya melibatkan tokoh, tindakan dan kejadian luar-alami (supranatural), dan meliputi beberapa ide umum mengenai gejala alam atau sejarah. Secara wajar dibedakan dari alegori dan legenda yang mengandung arti suatu inti kenyataan tetapi juga sering digunakan secara samar untuk meliputi pula penaturan yang mempunyai khayali. Banyak ahli mengatakan bahwa manusia, baik sebagai perorangan maupun sebagai kolektif, tidak dapat hidup tanpa mitos atau mitologi. Pengertian "mitos" seperti dikemukakan oleh para ilmuwan sosial, khususnya para antropolog misalnya memandang mitos sebagai sesuatu yang diperlukan manusia dalam mencari kejelasan tentang alam lingkungannya, juga sejarah masa lampaunya.

Dalam Al-Quran, kata yang mengandung makna mitos adalah kata asatir, kata tersebut merupakan jamak dari usturah. Jika dilihat dari kamus bahasa Arab, yaitu al-Munjid fi al-Lughah wa al-A'lam, kata asatirmempunyai arti cerita atau hikayah yang mengandung unsur imajinasi atau khayalan dari seorang pengisah. Begitu juga dalam kamus al-Munawwir diterangkan, bahwa kata asatir diartikan sebagai hikayat, cerita yang tidak ada asal-usulnya. Ada beberapa ayat dalam Alquran yang terdapat kata asatir,di antaranya adalah QS. al-An'am/6:25 yang berbunyi:

14 Farizal Alam, Z. Q. Hadis dan Mitos Jawa. Riwayah : Jurnal Studi Hadis, 3(1), 109. https://doi.org/10.21043/riwayah.v3i1.3440. 2018.

15 Peursen, C. A. Van, strategi kebudayaan (terj. Dick Hartoko), (Jakarta: Gunung Mulia, 1976), 37-38. 




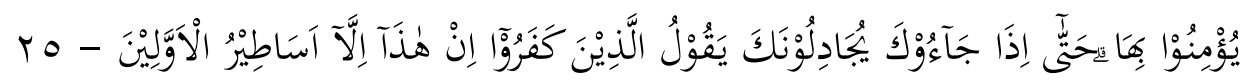

"Dan di antara mereka ada yang mendengarkan bacaanmu (Muhammad), dan Kami telah menjadikan hati mereka tertutup (sehingga mereka tidak) memahaminya, dan telinganya tersumbat. Dan kalaupun mereka melihat segala tanda (kebenaran), mereka tetap tidak mau beriman kepadanya. Sehingga apabila mereka datang kepadamu untuk membantahmu, orangorang kafir itu berkata, "Ini (Al-Qur'an) tidak lain hanyalah dongengan orang-orang terdahulu."

Ketika menafsirkan kalimat asatiru al-awwalinpada ayat di atas, alTabari meyatakan bahwa kata asatir merupakan jama' dari istaratun, dan usturatun. Mufrad dari kata tersebut bisa juga astarun. Sehingga, dari sini bisa di-ta'wil-kan bahwa asatiru al-awwalin mempunyai arti apa yang didongingkan oleh orang-orang terdahulu. Hal ini, menurut beliau, telah sesuai dengan apa yang di-ta'wil-kan Ibn 'Abbas. Sementara itu, Ibn Kathirmengartikan asatiral-awwalin sebagai kisah yang diambil dari kitab orang-orang terdahulu, dikutiplah kisah tersebut, dipelajari, kemudian diceritakan kepada orang-orang.Di dalam al-Kasysyaf, Zamakhsyari mengartikan asatirdengan khurafahyang berarti cerita bohong, khayalan, mitos, takhayul, legenda, dongeng, cerita yang dibuat-buat. Sementara itu, al-Qurtubi mengartikan asatir dengan al-abatil yang berarti kebatilan, tidak masuk akal, dusta, tidak benar, kebohongan, kepalsuan. Demikian juga, kata tersebut diartikan sebagai al-Turrahat yang berarti bualan, kesombongan, kepalsuan, omong kosong, kesesatan.

Namun, dari beberapa penafsiran di atas, tidak berarti menunjukkan adanya kisah mitos di dalam Alquran. Jika melihat redaksi ayat tersebut, kata asatir merupakan sikap yang ditunjukkan orang kafir terhadap Nabi Muhammad saw. dan sekali-kali bukan menunjukkan adanya kisah mitos dalam Alquran. Dengan kata lain, dari beberapa tafsir yang telah disebutkan, tidak satupun yang secara spesifik menyinggung adanya kisah mitos di dalam Alquran. Artinya, bahwa semua kisah yang terdapat dalam Alquran adalah benar adanya. Hal itu, telah ditegaskan oleh beberapa ulama tafsir. Di antaranya adalah Manna' Khalil al-Qattan. Ia menegaskan, bahwa semua kisah yang dikabarkan oleh Alquran adalah 
nyata dan sesuai dengan fakta sejarah ${ }^{16}$.

\section{F. Simpulan}

Ondel-ondel merupakan pertunjukan budaya rakyat Betawi diwariskan secara turun-temurun dari generasi ke generasi. Namun demikian, Seiring dengan perkembangan jaman ondel-ondel sudah tidak lagi menjadi benda yang sakral dan juga tidak lagi digunakan untuk ritual persembahan. Hasil penelitian menunjukan adanya perbedaan dan pergeseran makna mitos kebudayaan ondel-ondel. Pada zaman dahulu ondel-ondel hanya ditampilkan saat acara tertentu dan digubakan sebagai penolak nasib buruk. Dan masyarakat zaman dahulu cenderung masih mempercayai mitos kebudayaan ondel-ondel yang ada. Berbeda dengan zaman saat ini ondel-ondel dipakai untuk sarana untuk mendapatkan uang , Penelitian ini menyimpulkan bahwa terjadi pergeseran makna pada mitos kebudayaanondel-ondel dan mirisnya terjadi karena desakan faktor ekonomi dan urbanisasi yang terjadi di Jakarta.Kepercayaan terhadap mitos ondel-ondel mulai pudar tergerus oleh waktu. Penulis sangat menyayangkan akan penyalahgunaan yang terjadi pada zaman sekarang. Pada zaman sekarang peneliti belum meneumkan masyrakata yang masih percaya akan mitos kepercayaan ondel-ondel sebagai penolak bala.

Manfaat dan pentingnya dari penelitian ini antara lain guna untuk mengetahui aspek aspek apa saja yang sudah hilang dari kebudayaan ondel-ondel dari jaman dahulu hingga pada zaman sekarang. Dari penelitian ini pembaca dapat mengerti nilai nilai negatif dan positif yang diajarkan dari kebudayaan pada zaman dahulu tanpa mengambil nilai negatif. Cukup untuk dijadikan sebagai ilmu pengetahuan sejarah kebudayaan Betawi yang memiliki keunikan tersendiri dalam kesenianya dan tidak melupakan cerita sejarah yang sudah ada. Keunikan dari tulisan ini, pembaca bisa melihat dari sudut pandang tokoh masyarakat dari sesepuh masyarakat betawi dan sudut pandang anak muda masyarakat betawi. Hal ini, untuk mengetahui pandangan apa saja yang berbeda dari sudut pandang yang berbeda. Dan yang pasti, keunikan dari penelitian ini yakni pembaca bisa mengetahui bagaimana pandangan dan pemikiran yang dipikirkan dari para barongan atau mengisi ondel ondel yang sering

16 Islam, U., \& Sunan, N.. Kritik Atas Pemikiran Muhammad Ahmad Khalafullah Terhadap Ayat-Ayat Tentang Kisah Mitos Dalam Al-Qur'an. 2018.

$120 \mid$ JURNAL LISAN AL-HAL 
berkeliling di daerah Jakarta.

Kelemahan dari penelitian ini adalah jumlah subjek yang tidak terlalu banyak. Saran untuk peneliti selanjutnya agar bisa mencari subjek yang lebih banyak dan mengungkap masyarakat Jakarta yang masih percaya akan mitos kebudayaan ondel-ondel.

\section{DAFTAR PUSTAKA}

Chienita, I., Susanto, E. H., \& Winduwati, S. Persepsi Masyarakat Betawi Terhadap Fenomena Ondel-Ondel Ngamen. Koneksi, 2(2), 380. https://doi.org/10.24912/kn. v2i2.3913. 2019.

Design, G., Program, N. M., \& Departmen, F. A. (n.d.). Membaca Perubahan Tanda Visual dan Makna pada Ondel-ondel dalam Perkembangan Masyarakat Betawi.

Dewanti, A. R. Ondel-ondel sebagai ikon seni tradisi Betawi. Prosiding Seminar Nasional Seni Tradisi Keragaman Tradisi Sebagai Warisan Budaya 208-215. 20trieved from http://libprint.trisakti.ac.id/9/1/PROSIDING_A_Asih.pdf. 2014.

Faizah, N., Zid, M., \& Ode, S. H. Mobilitas sosial dan identitas etnis Betawi (Studi terhadap perubahan fungsi dan pola persebaran kesenian ondel-ondel di DKI Jakarta). Jurnal Spatial: Wahana Komunikasi Dan Informasi Geografi, 18(1), 36-50. Retrieved from http://journal.unj.ac.id/unj/index.php/spatial/article/download/74 23/5311. 2018.

Farizal Alam, Z. Q. Hadis dan Mitos Jawa. Riwayah : Jurnal Studi Hadis, 3(1), 109. https://doi.org/10.21043/riwayah.v3i1.3440. 2018.

Islam, U., \& Sunan, N.. Kritik Atas Pemikiran Muhammad Ahmad Khalafullah Terhadap Ayat-Ayat Tentang Kisah Mitos Dalam AlQur'an. 2018.

Majid, A. N., \& Ikhwan, M. Visualisasi Film Dokumenter Potret Pergeseran Fungsi Dan Penggunaan Ondel-Ondel Betawi. Journal of Chemical Information and Modeling, 110(9), 1689-1699. 2018.

Paramita, S. Pergeseran Makna Budaya Ondel-Ondel Pada. 1(1), 2018.

Rosita, D. Q. Perancanaan Tipografi Asimilasi Aksara Latin Karakteristik Ondel-Ondel sebagai Soludi Kreatif Melestarikan Budaya Betawi. Jurnal Desain, 2(2), 2014. 
"Pergeseran Nilai Spiritual Kebudayaan Ondel-Ondel"

Septi, G. Keperibadian manusia dalam perspektif psikologi Islam (telaah kritis atas psikologi kepribadian modern). Holistik, 12(1), 2011.

Wahidiyat, M. P. Ondel-ondel Sebagai Ruang Negosiasi Kultural Masyarakat. 2019.

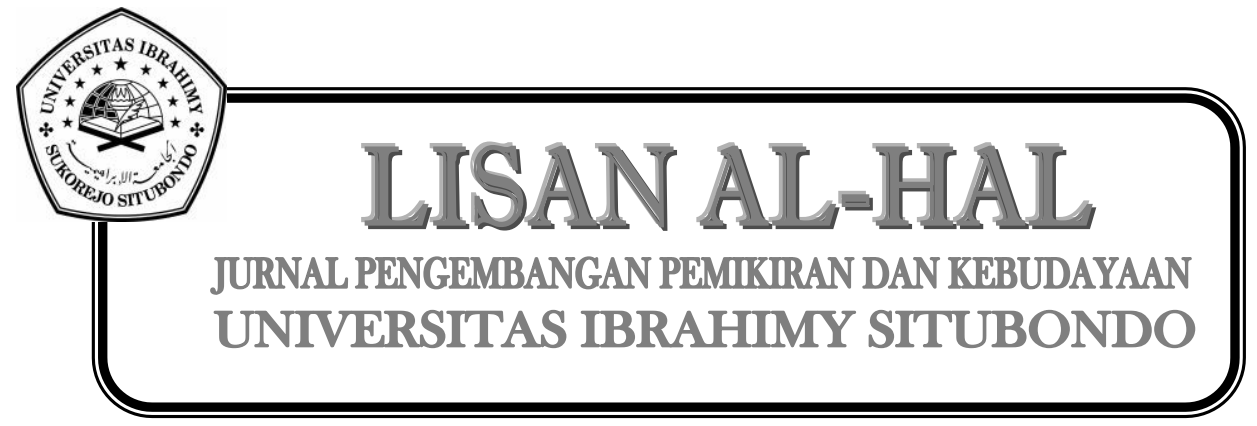

